Article

\title{
The Relation Between Husband Support with Exclusive Breastfeeding in Baby Age 6-12 Months in Air Dingin Health Center
}

\author{
Nurul Fitri ${ }^{1 *}$,Dr.dr.Yuniar Lestari,M.Kes,FISPH,FISCM ${ }^{2}$, Bd. Lisma Evareny, MPH ${ }^{3}$ \\ ${ }^{1.3}$ Departement of Midwifery, Faculty of Medicine, Andalas University, Padang, Indonesia \\ ${ }^{2}$ Department of Community Health Science, Faculty of Medicine Universitas Andalas Padang, Indonesia
}

\begin{tabular}{l} 
SUBMISSION TRACK \\
\hline Recieved: Oktober 28, 2017 \\
Final Revision: Nopember 03, 2017 \\
Available Online: Desember 15, 2017 \\
KEYWORDS \\
\hline exclusive breastfeeding, husbands support \\
CORRESPONDENCE
\end{tabular}

Phone: 085274286397

E-mail: nurul.fitrihilfa@gmail.com

\section{A B $\mathbf{S}$ T $\mathbf{T}$ R A $\mathbf{A}$ C $\mathbf{T}$}

Exclusive breastfeeding is one of ways to maintain a good growth and development for the baby. Exclusive breastfeeding in Indonesia is the right for every baby which is regulated in government regulations, but the coverage of exclusive breastfeeding is still low in some areas. The lowest exclusive breastfeeding coverage in Padang is in the working area of Air Dingin health center. The aims of this study is to determine the relationship between husbands support with exclusive breastfeeding in Air Dingin public health center.

This study was a quantitative study with cross sectional design conducted at Air Dingin health centerfrom Marchto December 2017. Subject of this studywere mothers who had 6-12 month babies whichwere106 people. Data was collected by using questionnaires and guided interviews. Data analysis was performed using univariate and bivariate using chi square test with $\mathrm{p}$-value $\leq 0,05$.

The results showed $76,4 \%$ of mothers did not provide exclusive breastfeeding for their babies and 59,4\% of mothers did not get support from their husbands.Bivariate analysis showed that there was a relationship between husband support with exclusive breastfeeding with p-value $=0.000$.

There was a relationship between husband support with providing exclusive breastfeeding for the babies. Because of the importance of husbands role, husbands must be the target for exclusive breastfeeding counseling.Therefore, husbands can also be active to find the information and participate in the success of exclusive breastfeeding for the babies. 


\section{INTRODUCTION}

International Confederation of Midwives (2011) states that one of ways to maintain good growth and development for baby is by breastfeeding. All the nutrients and energy baby needs during the first six months of birth can be fulfilledby the breast milk, the most optimal way to breastfeed the baby is by exclusive breastfeeding and supplementary feeding afterwards. Breastfeeding is a learning process and a natural process. In the implementation the mother needs active support in order to continue to maintain breastfeeding practices in her baby. One of the rights that have of mothers and families is to get accurate information about the benefits of breastfeeding and good breastfeeding management so that they get an idea of it and can make good decisions about what nutrients will be given to their baby.

United States Department of Agriculture (2002) suggested that fathers should be part of the breastfeeding team. There are several things that the father can do in breastfeeding teams such as, helping mothers complete work around the house, helping to keep the other child while the mother is breastfeeding the baby. If it is time to breastfeed a father or husband can also remind the mother and give the baby to the mother for breastfeeding. Helps to get the something that a mother needs when she is breastfeeding.Praising mother, making something special that can make mother always feel happy and good. Husband's support can make mothers feel relaxed and comfortable in breastfeeding practices and can also build confidencethat mothers is able to breastfeed babies even in public places.

Exclusive breastfeeding regulation in Indonesia is ratified in the ASI PP No. 33 of 2012. This government regulation aims to ensure that every baby gets the right to the fulfilled of exclusive breastfeeding. Ensure that every mother gets protection in giving exclusive breastfeeding to her baby and improve the support role of each part around the mother such as mother's husband, mother's family, health personnel and others.

Breast milk is the best food that has the most suitable content with the state of the baby's digestive system. One of the digestive diseases that often attacks the digestive system is diarrhea. While diarrhea in Indonesia is still one of the contributors of morbidity and mortality because the high morbidity and mortality in babies caused by diarrhea. It was reported that besides hygiene and environmental sanitation breastfeeding is also one factor that can reduce morbidity caused by diarrhea (Ministry of Health RI, 2011).

Hector, King and Web (2005) divide there are factors that affect exclusive breastfeeding into several factors: maternal and infant health status, mother's knowledge, skills and attitudes, infant feeding, public health care, regulatory, socio-cultural, economic and environmental characteristics, sociodemographic characteristics of mothers and families, social structures and support (family support including mother husband), information from mass media, and breastfeeding related norms developed in the community.

Based on research conducted by Brown \& Davies (2014) in the United Kingdom states that women who get strong social support from their husbands or partners have greater power in encouraging them to continue in breastfeeding to their babies. The study was conducted on 117 men whose partners had given birth in the past 2 years indicating that each father is eager to support their partner in breastfeeding the baby. But they feel marginalized in helping breastfeeding practices because they do not know what role they can play for helping their partners because of the minumum information they have about breastfeeding practices.

According to the Padang City Health Office 2016, inPadang city family support in exclusive breastfeeding is still relatively low, family support also includes husband support because the husband is the closest person to mothers who play a role during pregnancy, delivery and after birth, including exclusive 
breastfeeding . In Nainggolan (2014) appears that the support of husbands for wifein exclusivebreastfeeding amounted to $28.57 \%$. This small support also shows in the results fromSartono\&Utaminingrum(2012)research,

from 62 wives husband support in breastfeedingis only about $22.6 \%$.

Annual Report of Padang City Health office2016 edition reports that exclusive breastmilk coverage in Padang is $70.5 \%$.This achievement is not reach the target of exclusive breastmilk that is $80 \%$. There are only two puskesmas in Padang City that reach the target that isUlakKarang and Seberang Padang Puskesmasand rest almost all the public health centers in Padang City did not reach the target. Puskesmas Air Dingin is the area with the lowest exclusive breastmilk coverage in Padang City is $53.75 \%$.

Based on this phenomenon, the researcher are interested to examine more about the presence or absence of the husbandssupport with exclusive breastfeeding in the work area of Air Dinginpublic health center Padang city.

\section{METHODS}

This study was a quantitative study with cross sectional design, thestudy conducted in work area of Air Dingin Health Center from March 2016 to December 2017. Respondents of this study wasmothers who had 6-12 month babies whichwere106 people.Data Collected by quistionnaire. Data analysis was performed using univariate and bivariate.

\section{RESULT}

\section{Univariate Analysis}

Table1 Distribution of Exclusive Breastfeeding in the Working Area of Air Dingin Health Center

\begin{tabular}{lcc}
\hline \multicolumn{1}{c}{$\begin{array}{c}\text { Exclusive } \\
\text { Breastfeeding }\end{array}$} & $\begin{array}{c}\text { Frequency } \\
(\mathbf{f})\end{array}$ & $\begin{array}{c}\text { Percentage } \\
(\mathbf{\%})\end{array}$ \\
\hline $\begin{array}{l}\text { Not Exclusive } \\
\text { Breastfeeding }\end{array}$ & 81 & 76,4 \\
$\begin{array}{l}\text { Exclusive } \\
\text { Breastfeeding }\end{array}$ & 25 & 23,6 \\
\hline
\end{tabular}

Total 106 100,0
Based on Table 1 shows that most of
the respondents 81 of 106 respondents (76.4)
did not give exclusive breastfeeding to their
babies. Exclusive breastfeeding is when the
baby is only givenbreast milk without any
additional food such as water, formula,
honey, tea, porridge, biscuits and other solid
foods until the baby is six months old.
According to experts breastfeeding benefits
will increase during the first six months of
life if the baby is only given breast
milk.Increased breastfeeding is related to the
duration of breastfeeding to the babyand the
duration of breastfeeding after six months
accompanied by complementary food
(Roesli, 2012).

Table 2 Distribution of Husband Support in the Working Area of Air Dingin Health Center

\begin{tabular}{lcc}
\hline \multicolumn{1}{c}{$\begin{array}{c}\text { Husband } \\
\text { Support }\end{array}$} & $\begin{array}{c}\text { Frequency } \\
\text { (f) }\end{array}$ & $\begin{array}{c}\text { Persentage } \\
(\boldsymbol{\%})\end{array}$ \\
\hline Not Support & 63 & 59,4 \\
Support & 43 & 40,6 \\
\hline Total & 106 & 100,0 \\
\hline
\end{tabular}

Based on table 2 shows that more than half of respondents ie 63 of 106 respondents $(59.4 \%)$ did not get husband support. Husband support is needed to cultivate confidence of his wife. Husband is strongly encouraged to provide support and understanding of his wife so it will grow mutual understanding between husband and wife. More better support that provided by the husband will be higher the self-esteem wife in taking care of husband and child (Huliana, 2007).

Table 3 The Relation Between Husband Support With Exclusive Breastfeeding In Baby Age 6-12 Months In Air Dingin Health Center 


\begin{tabular}{|c|c|c|c|c|c|c|c|c|}
\hline \multirow{3}{*}{$\begin{array}{l}\text { Husband } \\
\text { Support }\end{array}$} & \multicolumn{4}{|c|}{ Exclusive Breastfeeding } & \multirow{2}{*}{\multicolumn{2}{|c|}{ Total }} & \multirow{3}{*}{$(95 \%$ CI) } & \multirow{3}{*}{$p$-value } \\
\hline & \multicolumn{2}{|c|}{$\begin{array}{l}\text { Not Exclusive } \\
\text { Breastfeeding }\end{array}$} & \multicolumn{2}{|c|}{$\begin{array}{c}\text { Exclusive } \\
\text { Breastfeeding }\end{array}$} & & & & \\
\hline & $f$ & $\%$ & $f$ & $\%$ & f & $\%$ & & \\
\hline $\begin{array}{c}\text { Not Support } \\
\text { Support }\end{array}$ & $\begin{array}{l}59 \\
22\end{array}$ & $\begin{array}{l}93,7 \\
51,2\end{array}$ & 21 & $\begin{array}{r}6,3 \\
48,8\end{array}$ & $\begin{array}{l}63 \\
43\end{array}$ & $\begin{array}{l}100 \\
100\end{array}$ & $\begin{array}{c}14,080 \\
(4,344-45,638)\end{array}$ & 0,000 \\
\hline Total & 81 & 76,4 & 25 & 23,6 & 106 & 100 & & \\
\hline
\end{tabular}

Based on Table 3 shows that the prevalence of mothers who did not give exclusive breastfeeding was more high for mothers who did not get husband support (93.7\%) than mothers who received husband support (51.2\%).

\section{DISCUSSION}

The prevalence of mothers who did not give exclusive breastfeeding was more high for mothers who did not get husband support $(93.7 \%)$ than mothers who received husband support $(51.2 \%)$. Based on the statistical test, $\mathrm{p}$-value $(\mathrm{p}=0,000)$ shows that there is a significant relationship in exclusive breastfeeding between mothers who are not supported by husbands with mothers who have the support of husbands. So it can be conclude that there is a relationship between the husbands support with exclusive breastfeeding in babies aged 6-12 months in the work area ofPuskesmas Air Dingin Padang City in 2017.

Research by Ferawati (2013) inKelurahanGondoriyo Semarang that get the same result that there is a relationship between husband support with exclusive breastfeeding with $\mathrm{p}$ value $=0,000$. According to research that has been done by Ferawati if the support provided by husband to mother is good then mother will be longer and happy to give breast milk to the baby. Husband's support will affect the mother's willingness to breastfeed and affect the duration of breastfeeding to the baby. This study also has the same findings as research conducted by Ramadani (2010) in the work area of Puskesmas Air Tawarin Padang that there is a relationship between husband support with exclusive breastfeeding with $p$ value $=0,020$. Any support provided by the
Based on the statistical test, p-value $(\mathrm{p}=0,000)$ shows that there is a significant relationship in exclusive breastfeeding between mothers who are not supported by husbands with mothers who have the support of husbands. So it can be conclude that there is a relationship between the husbands support with exclusive breastfeeding in babies aged 6-12 months in the work area ofPuskesmas Air Dingin Padang City in 2017.

husband will affect the mother's emotional state that will affect the production ofmilk.

This study did not get the same results as a study conducted by Oktalina (2015) in the Working Areas of Puskesmas Mengaluh Jombang that there is no relationship between husband support with exclusive breastfeeding with $\mathrm{p}$ value $=0.090$. According to research conducted by Oktalina the father factor is not the only factor that can affect exclusive breastfeeding to baby but there are other factors that also support exclusive breastfeeding. Such as the support factor of health personnel and support from the mother's family. These factors have been excluded and do not become one of the variables in this study.

Research conducted by Hani (2015) also get different results that there is no relationship between husband support with exclusive breastfeeding with $\mathrm{p}$ value $=1.00$. The difference in results is becauseof the lack understanding of mothers about breastfeeding and the mother's fear if breast milk does not enoughto the baby's needs and the false belief that babies need the other foodthan breast milk.

One way to exclusive breastfeeding runs smoothly requires good support from husbands and families. The husband can play a role and participate in supporting and assisting the work of the wife at home such as taking drinking water while the wife is breastfeeding the baby. Exclusive breastfeeding is in dire need of effort and 
good discipline from mothers, husbands and families.

The husband can also play a role in encouraging his wife to continue breastfeeding exclusively to her baby, reminding her wife to breastfeed the baby, giving praise to the wife for breastfeeding the baby well, so that will grow confidence and a great spirit for the wife to continue giving exclusive breastfeeding to the baby. The role and support of husband and the environment is very influential in providing support to the mother in taking care of her baby. The husband needs to understand the feelings and circumstances of his wife. This support will lead to positive attitudes and beliefs of the wife that the husband is there and ready to support it and struggle together in taking care of her baby (Indivara, 2009).

Government Regulation No. 33 of 2013 which regulates exclusive breastfeeding states that every baby has the right to receive exclusive breastfeeding from birth until six months of age with regard to its growth and development. The government through the law provides protection to the mother for giving the exclusive breastfeeding to her baby. It takes a good role and support from family, community and government towards exclusive breastfeeding.

\section{CONCLUSION}

1. Most of the respondents did not get husband support and most respondents did not give exclusive breastfeeding in the working area of Puskesmas Air DinginKota Padang.

2. There is a significant relationship between husband support with exclusive breastfeeding in the working area of Padang City Water Health Center in Padang 2017. 


\section{REFERENCES}

Arisman. 2009. GizidalamDaurKehidupan. EdisiKedua. EGC. Jakarta.

Atabik, A. 2014. Faktor Ibu Yang Berhubungan Dengan Praktik Pemberian ASI Eksklusif Di Wilayah Kerja Puskesmas Pamotan. 3 (1): 4-8.

BKKBN.2008. PendewasaanUsiaPerkawinandanHak-HakReproduksiBagiRemaja Indonesia. BKKBN. Jakarta.

Brown, A., Davies, R. 2014. Fathers' experiences of supporting breastfeeding: challenges for breastfeeding promotion and education. Maternal Child and Nutrition.10(4):510-526. Available at: https $/ /$ www.ncbi.nlm.nih.gov/pmc/a rticles 17 September 2017 (21.53).

Dahlan, M.S. 2014a. Langkah-Langkah Membuat Proposal Penelitian Bidang Kedokteran Dan Kesehatan Edisi 2. CV Sagung Seto Jakarta

DepartemenPendidikanNasional. 2003. Undang-UndangNomor 20 Tahun 2003. TentangSistemPendidikanNasional.Depdiknas. Jakarta

DinasKesehatan Kota Padang.2016. LaporanTahunanTahun 2015 Edisi 2016.Dinkes Kota Padang. Padang.

Dwiani, A. 2014.AnalisisFaktor-Faktor Yang BerhubunganDenganPemberian ASI Eksklusif Di PuskesmasDempo Palembang Dan PuskemasTimbanganOganIlir 2012.JurnalKesehatanMasyarakat. 5(1); 9-18.

Fahriani, R. dan R. Rohsiwatmo. 2014. Faktor yang MempengaruhiPemberian ASI EksklusifpadaBayiCukupBulan yang dilakukanInisiasiMenyusuDini. Sari Pediatri. 15(6):394-402

FerawatidanAnggorowati.2013. HubunganDukunganSuamiTerhadapPemberian ASI Di KelurahanGondoriyoN galiyan Semarang.144-148.

Hajaroh, H. 2013. HubunganSosialBudayadenganKeberhasilanPemberian ASI EksklusifpadaIbuMenyusui di Posyandu Wilayah desaSrigading Sanden Bantul Yogyakarta.SkripsiKebidananSekolahTinggiIlmuKesehatanAsyiyah Yogyakarta.

Hargi, JP. 2013. HubunganDukunganSuamidenganSikapIbuDalamPemberian ASI Eksklusif di Wilayah KerjaPuskesmasArjasaKabupatenJember.Skripsi.Prodi IlmuKeperawatanUniversitasJember.

Hector, D., King, L., Webb, K. 2005. Factors affecting breastfeeding practices Applying a conceptual framework. NSW Public Health Buletin. 16(4):52-55. Availableat: http://www.publish.csiro.au/paper/NB05013.htm. 8 Mei 2017 (01.34).

Hendarto, $\quad$ A., $\quad$ K. $\quad$ Pringgadini. 2013. NilaiNutrisi Air $\begin{array}{llll}\text { SusuIbu.http://www.idai.or.id/artikel/klinik/asi/nilai-nutrisi-air-susu-ibu. } & 8 & \text { Mei } & 2017\end{array}$ (00:18).

HPEQ. 2011. Draft Standar Kompetensi Bidan Indonesia. IBI. AIPKI. Dikti. Jakarta.

Huliana, M. 2007. PanduanMenjalaniKehamilanSehat. PuspaSwara. Jakarta

Indiarti, M.T., B.E Sukaca. 2015. NutrisiJanindanBayiSejakDalamKandungan.ParamaIlmu. Yogyakarta.

Indivara, N. 2009.The Mom's Secret. PenerbitPustakaAnggrek. Yogyakarta

International Confederation of Midwive. 2011. Position Statement : Breastfeeding. ICM. Durban.

Kementrian Kesehatan RI. Buletin Jendela Data dan Informasi Kesehatan : Situasi Diare Di Indonesia. Pusdatin Kemenkes RI. Jakarta.

KeputusanMenteriKesehatanRepublik Indonesia Nomor 450/Menkes/SK/IV/2004 Pemberian Air Susulbu ( ASI ) SecaraEksklusifPadaBayi Di Indonesia. 7 April 2004. Lembaran Negara Republik Indonesia.Menkes. Jakarta.

Khoiriyah, A. Prihatini, R. 2011. HubunganAntaraParitasdenganKeterampilanMenyusui yang BenarpadaIbuNifas, JurnalMidproedisi 2.1-5. 
Kurniawan,

B.

2013.DeterminanKeberhasilanPemberian

Eksklusif.JurnalKedokteranBrawijaya

Kurniawati, D.,R. Hargono.

2014.

FaktorDeterminan

Yang

MempengaruhiKegagalanPemberianAsiEksklusifPadaBayiUsia 6-12 Bulan Di

KelurahanMulyorejo Wilayah KerjaPuskesmasMulyorejo Surabaya. JurnalPromkes Indonesia 2(1): 15-27.

Lestari,D. Reni, Z. Larasati, TA. 2013. Hubungan Tingkat PengetahuanlbuTentang Air SusulbuDenganPemberian ASI Eksklusif Di KelurahanFajarBulan.Medical Journal of Lampung University. 2(4); 88-99.

Mamonto, T. 2015. Faktor-Faktor Yang BerhubunganDenganPemberian ASI EksklusifPadaBayi Di Wilayah KerjaPuskesmasKotobangonKecamatanKotamobaguTimur Kota Kotamobagu.56-66.

Maulida, H., E. Afifah.,D.P Sari. 2015. Tingkat EkonomidanMotivasilbudalamPemberian ASI $\begin{array}{lllll}\text { EksklusifpadaBayiUsia } & 0-6 & \text { Bulan di } & \text { BidanPraktekSwasta } & \text { (BPS) }\end{array}$ UmmiLatifahArgomulyo, Sedayu Yogyakarta. 3(2); 116-122.

Mira.Yulia, ID. Arneliwati. 2013. HubunganDukunganSuamiTerhadapMotivasilbuMemberi ASI padaBayiUsia 0-6 Bulan.

Molika, E. 2015.Tanya JwabSeputarKehamilandanMelahirkan.Vicosta Publishing. Jakarta Nainggolan,

2014.Hubungandukungansuamidengankeberhasilanisterimenyusui.Skripsi.FakultasKeper awatanUniversitasKatolikWidya Mandala Surabaya.

Nirwana, A.D. 2014. KandungandanManfaat ASI danSusu Formula.NuhaMedika. Yogyakarta.

Notoatmodjo, S. 2010. MetodologiPenelitianKesehatan. EdisiRevisi. PT. RinekaCipta. Jakarta.

Notoatmodjo, S.2012. PromosikesehatandanPerilakuKesehatan.Rinekacipta. Jakarta.

Nursalam.,N.D. Kurniawati.2007.Asuhan KeperawatanpadaPasienTerinfeksi HIV / AIDS. SalembaMedika. Jakarta.

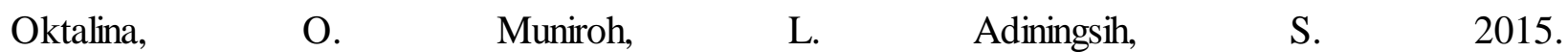
HubunganDukunganSuamidanDukunganKeluargadenganPemberian $\quad$ ASI

EksklusifpadaIbuAnggota KP-ASI. 10(1); 64-70

Peraturan Pemerintah Republik Indonesia Nomor 33 Tahun 2012 Pemberian Air Susu Ibu Eksklusif. Lembaran Negara Republik Indonesia Tahun 2009 Nomor 144. Jakarta.

Proverawati, A.,S. Asfuah. 2009. BukuAjarGizi. NuhaMedika. Yogyakarta.

Purwanti. 2004. KonsepPenerapan ASI Eksklusif. Cendekia. Bandung.

Reddy, S dan T. Abuka. 2016. Determinants of Exclusive Breastfeeding Practice among Mothers of Children Under Two Years Old In Dilla Zuria District, Gedeo Zone Snnpr Ethiopia. Diunduh pada tanggal 4 november 2017. Tersedia pada URL: https://www.omicsonline.org/open-access/determinants-of-exclusive-breastfeeding-practiceamong-mothers-ofchildren-under-two-years-old-in-dilla-zuria-district-gedeo-zone-s-2376$127 \mathrm{X}-1000224 . \mathrm{pdf}$

Rinata, E. 2015.TeknikMenyusui Yang BenarDitinjau Dari Usialbu, Paritas, UsiaGestasidanBeratBadanLahir di RSUD Siduardjo. JurnalMidwiferia. 1(1); 51-59

Roesli, U. 2012. Mengenal ASI Eksklusif. PustakaBunda. Jakarta

Rokhanawati, D. 2009. DukunganSosialSuamidanPerilakuPemberian ASI Ekslusif di KabupatenBantul Yogyakarta.Tesis Program PascaSarjanaFakultasKedokteranUniversitasGadjahMada.FakultasKedokteranUniversita sGadjahMada

Sartono, A., Utaminingrum, H. 2012. Hubunganpengetahuanibu, pendidikanibu, dandukungansuamidenganpraktekpemberianasieksklusif kelurahanMuktiharjoKidulkecamatanTelogosarikota JurnalGiziUniversitasMuhammadiyah Semarang. 1(1); 1-9

Semarang. 
Shanty, EF.2017. KarakteristikIbuBekerja yang BerhasilMemberikan ASI EksklusifpadaBayi di PuskesmasBanguntapan 1 Bantul Yogyakarta.JurnalPermata Indonesia. 8(1); 9-17.

Siswanto, dkk.2013. MetodelogiPenelitianKesehatandanKedokteran.Pustakallmu. Jakarta.

Soegoto, E.S. 2008.Marketing Research The Smart Way to Solve a Problem. Elex Media Komputindo. Bandung.

Somarwain, D. 2014. Peran ayah dan keberhasilan ibu menyusui selama enam bulan di posyandu Matahari RW III kelurahan Keputran kecamatan Tegalsari Surabaya.Skripsi. Fakultas Keperawatan Universitas Katolik Widya Mandala Surabaya.

Sulandari, T., T.S. Mulati.2014. HubunganDukunganSuamiDenganPemberian ASI Eksklusif Di PuskesmasSawit I KecamatanSawitKabupatenBoyolaliTahun 2014.21-18.

U.S. Department of Agriculture Food and Nutrition Service. 2002. Fathers Can SupportBreastfeeding.https://www.fns.usda.gov/sites/default/files/FathersCanSupportBFbrochure2.pdf.8 Mei 2017 (00:38).

Utami, HS. 2012. Faktor-Faktor Yang BerhubunganDenganPerilakulbuDalamPraktekPemberian ASI Eksklusif di Wilayah KerjaPuskesmasKecamatanKobaKabupaten Bangka Tengah Tahun 2012. Skripsi.FakultasKesehatanMasyarakatUniversitas Indonesia.

Wahyuni, D,.Machmudah.2013. DukunganSuamidalamPemberian ASI Eksklusif. 2(1); 93-101

Wiji, R.N. 2013.ASI danPedomanIbuMenyusui.NuhaMedika. Yogyakarta.

Yuliarti, N. 2010.Keajaiban ASI-MakananTerbaikuntukKesehatan, KecerdasandanKelincahan Si Kecil. C.V ANDI. Yogyakarta.

Yuliarti, Nurheti.2010. PanduanLengkapOlahragabagiWanitaHamildanMenyusui. CV ANDI. Yogyakarta 